\title{
Sustainable sugarcane initiative (SSI)-an approach to enhance sugarcane cultivation and input use efficiency and sustainable yield of sugarcane in India
}

\author{
Tulsi Parajuli ${ }^{1}$, Dharmendra Kumar Kurre ${ }^{1}$ and Sanjay Kumar Jangde* \\ Department of Agronomy, Rajmata Vijayaraje Scindia Krishi Vishwavidyalaya, \\ Gwalior (M.P.) India
}

\begin{abstract}
Sugar industry in India is the second largest agro-based industry in rural areas. Availability of sufficient sugarcane to sugar mills is pre-requisite for their efficient functioning. About 50 million farmers including their dependents and large number of agricultural labourers constituting 7.5 per cent of rural population are involved in sugarcane production which is utilized in 538 sugar mills with installed sugar production capacity of 32.93 million tonnes in 18 states. Sugarcane cultivation and the sugar industry in India are facing serious social, economic and environmental challenges. The increasing costs of cultivation and poor yields are making sugarcane cultivation economically unviable for farmers. Environmental issues like declining water table and degradation of soil pose other major threats to cane farmers and ecosystems. The productivity at the farm level has been stagnant at around 65-70 tonnes/ha over the last two decades. Unless we come up with a creative solution for our farmers, the crisis of water availability will keep intensifying and there will be a severe strain on our water sources. The sustainable sugarcane initiative (SSI) is a method of better management practices that involves use of less seeds, less water and optimum utilization of fertilizers and land to achieve more yield and profit for farmers and millers alike. It is an alternative to the conventional seed, water and space intensive sugarcane cultivation. Sustainable sugarcane initiative (SSI) has already helped over 5,000 farmers across India to improve their water productivity by 40 per cent, profits by 30 per cent, while reducing their ecological footprint. Several sugar mills and industries have begun to show great interest in this new and innovative method of sugarcane cultivation and are planning/ proposing to form into larger partnerships and networks with the proactive support of governments, banks, research institutions and civil society organizations.
\end{abstract}

Key Words : SSI, Wider spacing, Inter cropping, Integrated nutrient management, Integrated plant protection

View Point Article : Parajuli, Tulsi, Kurre, Dharmendra Kumar and Jangde, Sanjay Kumar (2019). Sustainable sugarcane initiative (SSI)-an approach to enhance sugarcane cultivation and input use efficiency and sustainable yield of sugarcane in India. Internat. J. agric. Sci., 15 (1) : 222-226, DOI:10.15740/HAS/IJAS/15.1/222-226. Copyright@ 2019: Hind Agri-Horticultural Society.

Article History : Received : 08.11.2018; Accepted : 29.12.2018

\footnotetext{
* Author for correspondence:

${ }^{1}$ Department of Agronomy, Dr. Rajendra Prasad Central Agricultural University, Pusa, Samastipur (Bihar) India
} 